\title{
Protokol Evaluasi Infeksi Virus Pasien Transplantasi Hati Anak
}

Mulya Rahma Karyanti, Nina Dwi Putri, Hanifah Oswari

Departemen Ilmu Kesehatan Anak RSUPN Cipto Mangukusumo, Fakultas Kedokteran Universitas Indonesia, Jakarta

Uji tapis terhadap infeksi virus sebelum transplantasi hati dapat memperkecil risiko reaktivasi atau transmisi infeksi virus dalam proses transplantasi hati. Pasien transplantasi hati akan mendapatkan terapi imunosupresan untuk mencegah rejeksi sehingga memperbesar risiko terkena infeksi. Cytomegalovirus (CMV), Ebstein-barr virus (EBV), dan Herpes Simplex Virus (HSV) merupakan virus penyebab tersering komplikasi infeksi pada pasien transplan hati. Komplikasi disebabkan oleh CMV, antara lain, viral syndrome, hepatitis, pneumonitis, dan kolitis. Ebstein-Barr Virus dapat menyebabkan Post-transplant Lymphoproliferative Disorder (PTLD). Infeksi HSV pasien transplan hati akan memberikan manifestasi klinis yang lebih berat dan respon terapi yang lambat. Makalah ini bertujuan untuk membuat protokol evaluasi infeksi virus pada saat uji tapis, pencegahan dan tata laksana antivirus untuk pasien transplantasi hati. Sari Pediatri 2018;20(4):258-64

Kata kunci: infeksi, virus, transplantasi hati, CMV, EBV, HSV

\section{Protocol of Evaluation Viral Infection in Children Liver Transplant Patients}

Mulya Rahma Karyanti, Nina Dwi Putri, Hanifah Oswari

Viral infection screening in liver transplantation patient is crucial to be performed in order to minimize the risk of infection reactivation or transmission. Liver transplant patients will be administered immunosuppressants agents to prevent rejection, therefore could increase the risk of infection. The CMV, EBV and HSV infection are the most frequent cause of infectious complication following liver transplant patient. Complications caused by CMV infection are viral syndrome, hepatitis, pneumonitis, and colitis. EBV infection can cause Posttransplant Lymphoproliferative Disorder (PTLD). The HSV infection in liver transplant patient has more severe clinical manifestation of HSV and lower response to therapy. This article aims to create protocol for viral infection screening, prophylaxis, and treatment for liver transplant patient. Sari Pediatri 2018;20(4):258-64

Keywords: infection, viral, liver tranplantation, CMV, EBV, HSV

Alamat korespondensi: Mulya Rahma Karyanti. Departemen Ilmu Kesehatan Anak RSUPN Cipto Mangukusumo, Fakultas Kedokteran Universitas Indonesia, Jl. Diponegoro No.71 Salemba, Jakarta Pusat. Email: karyanti@ikafkui.net 
$\mathrm{V}$

irus merupakan mikroorganisme berukuran kecil, berdiameter sekitar $20-300 \mathrm{~nm}$, bersifat parasit obligat intraselular yang hanya terdiri dari protein dan asam nukleat, baik berupa DNA atau RNA. ${ }^{1}$ Virus merupakan penyebab tersering infeksi oportunistik pasca-transplantasi hati. Komplikasi infeksi tersebut dapat berkaitan dengan pemberian terapi imunosupresif. Cytomegalovirus (CMV) adalah patogen tersering yang menyebabkan infeksi pasca-transplantasi hati (18\%-29\%) yang tidak mendapatkan profilaksis. ${ }^{2}$ Meskipun demikian, beberapa virus lain juga dapat menyebabkan infeksi pasca-transplantasi hati, seperti Epstein-Barr virus dan Herpes virus. ${ }^{3}$ Infeksi EBV terjadi pada 3\%-12\% pasien pasca-transplantasi hati pada anak. ${ }^{4}$ Sementara herpes virus dengan jenis herpes simplex virus (HSV) terjadi pada $40 \%$ pasien pasca-transplantasi yang tidak mendapat profilaksis sebelumnya. ${ }^{5}$ Pada uji tapis yang dilakukan sebelum transplantasi hati di Rumah Sakit Cipto Mangunkusumo (RSCM), dari 41 kasus, 37 $(90,2 \%)$ kasus terinfeksi virus CMV, 11 (26,8\%) terinfeksi virus EBV, dan 20 (48,7\%) terinfeksi virus HSV. Oleh sebab itu, pemeriksaan uji tapis perlu dilakukan untuk virus tersebut pada resipien dan donor agar dapat mendeteksi infeksi laten dan aktif sehingga mengoptimalkan kondisi setelah transplantasi. Bila dilakukan, hal ini dapat mencegah terjadinya reaktivasi infeksi virus pada resipien pasca-transplantasi organ. Terapi profilaksis atau preemptive yang tepat, bertujuan memberikan pengawasan infeksi virus pasca-transplantasi. ${ }^{1}$

Protokol ini bertujuan untuk mendeteksi infeksi virus pada pasien pre dan pasca-transplantasi hati untuk mencegah atau mengurangi risiko terjadinya transmisi infeksi virus. Protokol dibuat berdasarkan klasifikasi level of evidence yang dikeluarkan oleh Oxford Centre for Evidence-based Medicine yang dimodifikasi untuk keperluan praktis. Peringkat bukti yang digunakan adalah (1) level I, yaitu meta analisis atau Randomize Clinical Trial (RCT) double blind (uji klinis acak tersamar ganda); (2) level II, yaitu RTC non double blind (uji klinis acak tidak tersamar ganda terandomisasi / non randomisasi); level III, yaitu studi observasional (kohort, potong lintang, kasus kontrol); level IV, yaitu konsensus dan pendapat ahli. Berdasarkan derajat rekomendasi peringkat bukti maka dibuat rekomendasi sebagai berikut, rekomendasi A bila berdasar pada bukti level I, rekomendasi B bila berdasar pada bukti level II, rekomendasi C bila berdasar pada bukti level III, dan rekomendasi D bila berdasar pada bukti level IV.

\section{Cytomegalovirus (CMV)}

Infeksi CMV sering diperoleh melalui transplantasi organ. Berdasarkan serologi CMV, faktor risiko untuk penyakit Cytomegalovirus pada transplantasi organ dibagi menjadi tiga, yaitu risiko tinggi: $\mathrm{D}+\mathrm{R}-$ (donor seropositif/ resipien seronegatif), risiko sedang: $\mathrm{D}+$ / $R+$ (donor seropositif / resipien seropositif) dan $\mathrm{D}-/ \mathrm{R}+$ (donor seronegatif / resipien seropositif, dan risko ringan: D-/ R- (donor seronegatif / resipien seronegatif). ${ }^{6,7}$

\section{Uji tapis infeksi CMV}

Pemeriksaan uji tapis donor dan resipien harus dilakukan untuk mendeteksi apakah terdapat infeksi CMV sebelumnya (laten) dengan menggunakan pemeriksaan serologi yang bertujuan menilai risiko dan menentukan pemantauan yang sesuai dan/ atau pemberian profilaksis antiviral pasca tranplantasi. ${ }^{6,7}$

Infeksi CMV dipertimbangkan jika salah satu dari beberapa pemeriksaan ini ditemukan, yaitu (1) serokonversi dengan kemunculan IgM anti-CMV; (2) peningkatan 4 kali lipat titer IgG; (3) deteksi antigen CMV pada sel yang terinfeksi; (4) deteksi CMVDNAemia dengan menggunakan teknik molekular; (5) dan/ atau isolasi virus dengan menggunakan kultur tenggorok, buffy coat, atau urin. Saat ini, ketersediaan pemeriksaan PCR CMV digunakan untuk menggantikan cara lama di atas.

Penyakit CMV ditandai dengan tanda dan gejala, seperti demam, leukopenia, dan keterlibatan organ. Pengobatan hanya diberikan pada saat penyakit CMV sedang terjadi, bukan pada infeksi laten. Saat ini, terdapat dua pendekatan utama untuk membantu mencegah penyakit CMV pada pasien yang akan menjalani transplantasi, yaitu (I) strategi preemptive dengan melakukan monitoring viremia dari infeksi CMV dengan menggunakan PCR CMV serial dan (II) strategi profilaksis dengan memberikan obat antiviral pada pasien yang memiliki risiko tinggi terjadinya infeksi CMV. ${ }^{8}$

\section{Strategi Terapi Preemptive CMV}

Strategi Preemptive digunakan pada transplantasi hati di RSCM, yaitu dengan memonitor PCR kuantitatif CMV untuk menilai replikasi virus CMV. Dosis terapi 
Mulya Rahma Karyanti dkk: Protokol evaluasi infeksi virus pasien transplantasi hati anak

diberikan jika ambang batas kadar virus PCR CMV $\geq 5000 \mathrm{kopi} / \mathrm{uL}$ sebelum munculnya gejala. ${ }^{9}$ Terapi yang digunakan di RSCM, yaitu gansiklolovirintravena dengan dosis terapi $5 \mathrm{mg} / \mathrm{kgBB} / 12$ jam selama 2 minggu dilanjutkan dengan valgansiklovir $(15 \mathrm{mg} /$ $\mathrm{kg}$ BB per dosis setiap 12 jam) per oral selama 4 minggu. Pemberian terapi gansiklovir intravena dengan dosisprofilaksis $5 \mathrm{mg} / \mathrm{kg} \mathrm{BB} / 24$ jam diberikan jika kadar virus PCR CMV $<5000$ kopi/uL. ${ }^{10}$

\section{Rekomendasi preemptive therapy}

Terapi ini efektif untuk mencegah CMV pada pasien yang berisiko menderita penyakit CMV (I). Frekuensi monitoring adalah 1-2 kali per minggu selama 12 minggu pasca-transplantasi (II-2). Terapi antiviral yang direkomendasikan adalah gansiklovirintravena ( 5 $\mathrm{mg} / \mathrm{kg} / 12 \mathrm{jam}$ ) selama 2 minggu dilanjutkan dengan valgansiklovir (15 mg/kg per dosis setiap $12 \mathrm{jam}$ ) per oral dosis terapi selama 4 minggu (I). Terapi antiviral harus dilanjutkan sampai CMV DNAemia atau antigenemia tidak lagi terdeteksi (II-2). ${ }^{10,11}$

Monitoring laboratorium dengan QNAT atau $p p 65$ antigenemia direkomendasikan dilakukan sekali dalam seminggu untuk melihat respon terapi antiviral pada infeksi CMV dan melihat adanya risiko infeksi CMV setelah pemberian terapi preemptive untuk mencegah infeksi tersebut (II-2). ${ }^{11}$

Di RSCM dilakukan pemeriksaan darah EDTA untuk menilai PCR kuantitatif CMV dan diperiksa pasca-transplantasi hati sebelum memulai terapi. Jika hasil positif untuk CMV, pasien harus diobati sampai kadar virus CMV (PCR) tidak terdeteksi dalam dua sampel yang berurutan. Setelah tata laksana, kadar virus pasien harus dimonitor setiap 2 minggu dalam 3 bulan. ${ }^{12}$ Dosis obat immunosupresif perlu diturunkan saat dilakukan pemberian terapi antivirus. ${ }^{3}$

\section{Strategi terapi profilaksis CMV}

Pada beberapa pusat transplantasi hati di luar negeri, pasien berisiko tinggi harus menerima profilaksis antiCMV dengan valgansiklovir selama 3 bulan, dimulai 1 bulan setelah transplantasi. Dosis didasarkan pada fungsi ginjal (pada setiap kunjungan klinik, dosis harus ditinjau ulang). Pemeriksaan PCR CMV dilakukan sebelum memulai profilaksis. ${ }^{12}$ Durasi profilaksis disesuaikan dengan status CMV donor/ resipien transplan seperti yang tertera pada Tabel 1 .
Tabel 1. Profilaksis CMV ${ }^{14}$

\begin{tabular}{ll}
\hline $\begin{array}{l}\text { Status CMV donor/ } \\
\text { resipien transplan }\end{array}$ & Durasi profilaksis \\
\hline $\mathrm{D}_{+} / \mathrm{R}-$ & Valgansiklovir-6 bulan \\
$\mathrm{D}+/ \mathrm{R}+$ & Valgansiklovir-3 bulan \\
$\mathrm{D}-/ \mathrm{R}+$ & Valgansiklovir-3 bulan \\
$\mathrm{D}-/ \mathrm{R}-$ & Tidak ada profilaksis \\
\hline
\end{tabular}

$\mathrm{D}=$ donor; $\mathrm{R}=$ resipien; $\mathrm{D}+=$ donor seropositif; $\mathrm{D}-=$ donor seronegatif; $R_{+}=$resipien seropositif; $\mathrm{R}-=$ resipien seronegatif

Pasien yang menerima imunosupresan standar, monitoring PCR CMV harus dilakukan setiap bulan selama 6 bulan pertama pasca-transplantasi. Pengukuran tersebut diulang pada bulan ke-12 pascatransplantasi. ${ }^{12}$

Pasien berisiko rendah tidak membutuhkan monitoring PCR CMV maupun profilaksis. Kadar virus $\mathrm{CMV}$ dilakukan jika pasien terduga mengalami penyakit CMV. ${ }^{12}$

Pemberian dosis gansiklovir dan valgansiklovir yang tepat penting untuk dilakukan. Dosis yang tidak optimal mengurangi efektivitas dan meningkatkan resistensi obat. Namun, pemberian dosis yang berlebihan dapat menyebabkan efek samping. Efek samping gansiklovir dan valgansiklovir berupa leukopenia karena obat tersebut memiliki efek mielotoksik sehingga perlu dilakukan pemeriksaan darah perifer lengkap setiap 3 hari. Monitoring laju filtrasi glomerulus dilakukan selama pemberian terapi antivirus. Dosis dan waktu pemberian antivirus diberikan sesuai dengan nilai klirens kreatinin. ${ }^{13}$

Terapi profilaksis CMV dapat segera diberikan. Valgansiklovir tersedia sebagai tablet $450 \mathrm{mg}$ dan solusio oral $250 \mathrm{mg} / 5 \mathrm{~mL}$. Tablet tersebut tidak boleh dihancurkan karena sifat sitotoksik alami obat. Dosis profilaksis valgansiklovir adalah $520 \mathrm{mg} / \mathrm{m}^{2}$ (maksimal $900 \mathrm{mg}$ ) sekali sehari (dengan pertimbangan pasien memiliki eGFR $>80 \mathrm{~mL} / \mathrm{menit} / 1,73 \mathrm{~m}^{2}$ ). Jika eGFR kurang dari angka tersebut, dosis dihitung berdasarkan formula di bawah ini, ${ }^{12}$

\section{Dosis $(\mathrm{mg})=7 \times$ BSA $\left(\mathrm{m}^{2}\right) \times$ eGFR $(\mathrm{mL} /$ menit/1,73 $\mathrm{m}^{2}$ ) diberikan $1 \mathrm{kali} / \mathrm{hari}$}

BSA $=$ Body Surface Area

$\mathrm{GFR}=$ Glomerular Filtration Rate

Jika menggunakan valgansiklovir oral, dosis terapi tertera pada Tabel 2. Jika menggunakan gansiklovir 
intravena, dosis terapi tertera pada Tabel 3. Profilaksis CMV pada transplantasi hati tertera pada Tabel $4 .{ }^{9}$

\section{Pasca-transplantasi}

Semua resipien pasca-transplantasi hati, kecuali serologi CMV D-/ R-, menerima kemoprofilaksis infeksi CMV dengan gansiklovir IV atau valgansiklovir oral selama setidaknya 3 bulan pasca-transplantasi (1-B), dan selama 6 bulan setelah tata laksana T-cell-depleting antibody (1-C). ${ }^{11}$

Pada pasien dengan penyakit CMV, direkomendasikan monitoring perminggu dengan PCR kuantitatif CMV ataupun pp65 antigenemia (2-D). Tata laksana CMV dianjurkan untuk dilanjutkan sampai CMV tidak terdeteksi lagi dengan PCR kuantitatif CMV atau NAT plasma ataupun $p p 65$ antigenemia (2-D). ${ }^{11}$

\section{Epstein-Barr virus (EBV)}

\section{Uji tapis infeksi EBV}

Infeksi Epstein-Barr virus dapat mengakibatkan Posttransplant Lymphoproliferative Disorder (PTLD). Transmisi EBV pada resipien seronegatif merupakan faktor risiko terbesar terjadinya PTLD 4\%-22\%. ${ }^{16}$ Oleh karena itu, EBV D+/ R-, terutama pada anak, membutuhkan pemantauan virus EBV secara berkala dan diberiterapi jika viremia teridentifikasi. ${ }^{1}$ Penyakit PTLD dapat juga

Tabel 2. Pedoman pemberian dosis valgansiklovir ${ }^{14}$

\begin{tabular}{lcc}
\hline Pasien & Dosis (mg secara oral) & Frekuensi \\
\hline$<50 \mathrm{~kg}$ & $7 \times$ BsA x GFR (Schwartz equation) $\mathrm{mg}$ & $\mathrm{mg} /$ hari \\
$>50 \mathrm{~kg}$ (tergantung GFR) & $900 \mathrm{mg}$ & Sekali sehari \\
$>60 \mathrm{~mL} /$ menit & $450 \mathrm{mg}$ & Sekali sehari \\
$40-59 \mathrm{~mL} /$ menit & $450 \mathrm{mg}$ & Selang sehari \\
$25-39 \mathrm{~mL} /$ menit & $450 \mathrm{mg}$ & Dua kali seminggu \\
$10-24 \mathrm{~mL} /$ menit & $450 \mathrm{mg}$ & Dua kali seminggu (setelah dialisis, apabila \\
$<10 \mathrm{~mL} /$ menit & & bergantung dialisis) \\
& &
\end{tabular}

Tabel 3. Dosisgansiklovir intravena ${ }^{12}$

\begin{tabular}{lll}
\hline eGFR $\left(\mathrm{mL} / \mathrm{menit} / 1,73 \mathrm{~m}^{2}\right)$ & Dosis terapi & Dosis profilaksis \\
\hline$\geq 70$ & $5 \mathrm{mg} / \mathrm{kg} \mathrm{BB} / 12 \mathrm{jam}$ & $5 \mathrm{mg} / \mathrm{kg} \mathrm{BB} / 24 \mathrm{jam}$ \\
$50-69$ & $2,5 \mathrm{mg} / \mathrm{kg} \mathrm{BB} / 12 \mathrm{jam}$ & $2,5 \mathrm{mg} / \mathrm{kg} \mathrm{BB} / 24 \mathrm{jam}$ \\
$25-49$ & $2,5 \mathrm{mg} / \mathrm{kg} \mathrm{BB} / 24 \mathrm{jam}$ & $1,25 \mathrm{mg} / \mathrm{kg} \mathrm{BB} / 24 \mathrm{jam}$ \\
$10-24$ & $1,25 \mathrm{mg} / \mathrm{kg} \mathrm{BB} / 24 \mathrm{jam}$ & $0,625 \mathrm{mg} / \mathrm{kg} \mathrm{BB} / 24 \mathrm{jam}$ \\
$<10$ (pasien dalam hemodialisis) & $1,25 \mathrm{mg} / \mathrm{kg} \mathrm{BB} / 24 \mathrm{jam}$ (diberikan & $0,625 \mathrm{mg} / \mathrm{kg} \mathrm{BB} / 24 \mathrm{jam}$ (diberikan setelah \\
& setelah dialisis pada hari hemodialisis) & dialisis pada hari hemodialisis) \\
\hline
\end{tabular}

Tabel 4. Monitoring dan profilaksis yang direkomendasikan untuk pencegahan CMV ${ }^{9}$

\begin{tabular}{|c|c|c|c|}
\hline Organ & Serostatus* & $\begin{array}{c}\text { Tingkat } \\
\text { risiko }\end{array}$ & Monitoring dan profilaksis yang direkomendasikan \\
\hline \multirow[t]{2}{*}{ Hati } & D-/ R- & Rendah & $\begin{array}{l}\text { Profilaksis:gansiklovir IV sekali sehari sampai pasien mampu mengkonsumsi } \\
\text { asiklovir oral sampai } 120 \text { hari pasca-transplantasi } \\
\text { Monitoring serial: Setiap } 2 \text { minggu sekali dalam } 3 \text { bulan pertama dan setiap } \\
\text { sebulan sekali dalam } 1 \text { tahun pasca-transplantasi }\end{array}$ \\
\hline & $\mathrm{R}+$ atau $\mathrm{D}+/ \mathrm{R}-$ & Tinggi & $\begin{array}{l}\text { Profilaksis: dengan gansiklovirIV sekali sehari sampai pasien mampu meng- } \\
\text { konsumsi valgansiklovir oral sampai } 120 \text { hari pasca-transplantasi. } \\
\text { Monitoring serial: sama dengan pasien risiko rendah }\end{array}$ \\
\hline
\end{tabular}


terjadi pada resipien seropositif di bawah pengaruh penambahan imunosupresi (obat-obatan imunosupresi). Dengan adanya pemeriksaan serologi pra-transplantasi pada semua donor dan resipien maka dapat menargetkan kelompok risiko tertinggi untuk monitoring ketat dengan PCR EBV dan preemptive interventions, seperti penurunan imunosupresi.?

\section{Rekomendasi}

Baik donor dan resipien harus dilakukan uji tapis infeksi EBVmenggunakan serologi, terutama jika resipien adalah anak (A-II). ${ }^{7}$ Pada pusat transplantasi anak, serologi EBV harus dilakukan pada donor dan resipien transplan hati (II-2). ${ }^{6}$ Pasca transplantasi hati pemeriksaan PCR EBV direkomendasikan untuk dilakukan setiap 2 minggu.

\section{Profilaksis dan Terapi EBV}

Beberapa rumah sakit pusat di bawah ini memberikan profilaksis EBV. Dosis gansiklovir adalah $5 \mathrm{mg} / \mathrm{kg}$ $\mathrm{BB} / 12$ jam sebagai dosis awal (tiga minggu pertama), yang kemudian diikuti $5 \mathrm{mg} / \mathrm{kg} /$ hari. ${ }^{11}$ Terapi pada pasien dengan infeksi EBV asimtomatik dengan PCR EBV positif diberikan apabila PCR EBV $\geq 1000 \mathrm{kopi} /$ mcg DNA pada dua kali pemeriksaan dan hasil CD23 dan CD10 positif. Dosis immunosupresan sebaiknya diturunkan untuk mendapatkan level immunosupresan yang lebih rendah.

Pada risiko tinggi EBV (D+ / R-), pemberian terapi antivirus dan immunoglobulin memiliki manfaat dalam mencegah infeksi EBV maupun penyakit PTLD akibat EBV..$^{15}$ Immunoglobulin intravena diberikan $100 \mathrm{mg} / \mathrm{kg}$ BB setiap 2 minggu dimulai 24-72 jam pasca-transplantasi diberikan selama 12 minggu.

Dosis terapi gansiklovir intravena $5 \mathrm{mg} / \mathrm{kg} \mathrm{BB} / 12$ jam diberikan selama tiga minggu pertama, kemudian diikuti dosis terapi valgansiklovir oral selama 3 bulan dan selanjutnya diberikan dosis profilaksis valgansiklovir selama 3 bulan.

\section{Uji tapis EBV pasca-transplantasi}

Monitoring risiko tinggi (D+/ R-) untuk EBV dengan menggunakan PCR EBV kualitatif/kuantitatif. Sekali pada minggu pertama setelah transplantasi. Kemudian setidaknya sebulan sekali dalam 3-6 bulan pertama setelah transplantasi (2-D), setiap 3 bulan sampai akhir tahun pertama pasca-transplantasi (2-D), dan setelah tata laksana rejeksi akut. ${ }^{16}$

Sampai saat ini, bukti penggunaan profilaksis untuk EBV masih belum cukup. Namun, profilaksis dipertimbangkan atas alasan mencegah infeksi primer, mencegah penyakit simptomatik, seperti: Post-transplant Lymphoproliferative Disorder (PTLD), febrile syndrome (mononucleosis-like ilness), dan end organ diseases (supresi sumsum tulang, enteritis, hepatitis, serta ensefalitis). ${ }^{16}$

Kejadian PTLD akan sulit dihindari selama dosis imunosupresan dinaikkan (awal bulan setelah transplantasi) jika tidak ada pencegahan hal tersebut di atas.

Tabel 5. Regimen yang digunakan beberapa rumah sakit pusat transplantasi sebagai obat profilaksis penyakit akibat EBV virus pada pasien dengan donor EBV-seropositif, resipien seronegatif D+R- ${ }^{11}$

\begin{tabular}{ll}
\hline Rumah sakit pusat & Regimen (untuk EBV D+R-) \\
\hline Toronto Hospital (dewasa) & Ganciclovyr x 12 minggu \\
The Hospital for Sick Children & Ganciclovyr +Cytogam* x 12 minggu \\
University of Alberta Hospital (dewasa dan anak) & Ganciclovyr x 12 minggu \\
Hopital Ste-Justine (anak) & Tidak ada profilaksis kecuali CMV D+R- \\
Montreal Children Hospital & Ganciclovyr +Cytogam* x 12 minggu \\
Winnipeg Children Hospital & Ganciclovyr x 12 minggu \\
Royal University Hospital (saskatchewan) & Berdasarkan profilaksis CMV: \\
& Semua resipien transplantasi menerima profilaksis CMV \\
London Health Science Centre (anak) & termasuk (CMV D-R-) \\
& Berdasarkan profilaksis CMV: \\
& Semua anak mendapat immunoglobulin + acyclovir x \\
\hline
\end{tabular}

*Massachusetts Public Health Biologic Laboratories, USA. CMV cytomegalovirus; Donor D-R-EBV-seronegatif, resipien seronegatif 


\section{Herpes-virus}

\section{Uji tapis herpes virus}

Herpesvirus yang memiliki kepentingan klinis pada resipien transplantasi adalah Herpes simplex virus (HSV1 dan HSV-2) dan Varicella-zoster virus (VZV). Uji tapis HSV dilakukan oleh beberapa rumah sakit pusat transplantasi, tetapi beberapa pusat lain memberikan profilaksis antiviral acyclovir selama setidaknya 1-3 bulan pasca-transplantasi. Infeksi varicella pascatransplantasi dapat bersifat fatal. Oleh karena itu, uji tapis VZV pada resipien sangat penting yang dilanjutkan dengan vaksinasi resipien seronegatif pratransplantasi, jika semuanya memungkinkan (III). 7,15,17

Sebelum melakukan tranplantasi hati harus dilakukan pemeriksaan IgG HSV pada resipien. Pemeriksaan serologi IgG dilakukan pada pre-transplantasi untuk melihat adanya risiko pasca-transplantasi. Resipien dengan seropositif HSV tanpa profilaksis antivirus sebelumnya memiliki risiko reaktivasi virus HSV pascatransplantasi meskipun sebelumnya tidak ada riwayat penyakit oleh infeksi HSV. ${ }^{18}$

\section{Profilaksis dan terapi HSV}

Resipien transplan hati yang menerima antivirus CMV, berupa gansiklovir, valasiklovir, atau valgansiklovir dalam dosis standar juga dapat mencegah replikasi HSV. Profilaksis spesifik untuk HSV diberikan pada semua HSV-1 dan HSV-2 seropositif resipien yang tidak mendapat terapi antivirus CMV. Profilaksis HSV pada pasien anak tidak rutin diberikan secara universal. Anak yang berusia 2 tahun atau lebih membutuhkan terapi asiklovir per oral $10 \mathrm{mg} / \mathrm{kg} \mathrm{BB} / \mathrm{kali}$ interval 6 jam. Terapi asiklovir intravena direkomendasikan $5 \mathrm{mg} / \mathrm{kg}$ dengan interval 8 jam. Penyakit HSV berat muncul di bulan pertama setelah transplantasi hati. Jadi, profilaksis asiklovir perlu dilanjutkan paling sedikit satu bulan (I). Profilaksis dipertimbangkan dimulai kembali pada pasien yang akan diterapi imunosupresan untuk mencegah rejeksi (III). ${ }^{18}$

Pasien yang menerima profilaksis antivirus CMV (gansiklovir/valgansiklovir) dilanjutkan hingga $\geq 100$ hari dan tidak memerlukan tambahan pencegahan HSV. Pada pasien yang mengalami kekambuhan setelah menghentikan terapi antivirus, terapi antivirus supresif harus dilanjutkan hingga level imunosupresan dapat diturunkan (I). Terapi supresif aman dilanjutkan untuk beberapa tahun dengan kejadian resistensi lebih sedikit dibandingkan dengan terapi episodik pada pasien immunocompromised (III). Apabila penghentian profilaksis tidak berhasil, maka terapi supresif seumur hidup mungkin diperlukan. ${ }^{18}$

\section{Kesimpulan}

Komplikasi infeksi virus pasca-transplantasi dapat berakibat kematian. Oleh sebab itu, uji tapisinfeksi virus pre dan pasca transplantasi serta pemberian profilaksis antivirus yang sesuai dengan patogen penyebab infeksi sangat penting dalam rangkaian proses pre dan pasca-transplantasi hati sehingga menurunkan angka morbiditas dan angka mortalitas serta memperbaiki tingkat harapan hidup pascatransplantasi hati.

\section{Daftar pustaka}

1. Burrell CJ, Howard CR, Murphy FA. Fenner and White's medical virology. Edisi ke-5. Oxford: Elsevier; 2017.h.15-26, 39-55, 16983.

2. Verma Y, Gupta E, Kumar N, Hasnain N, Bhadoria A, Pamecha V, Khanna R. Earlier and higher rates of cytomegalovirus infection in pediatric liver transplant compare to adults: An observastional study. J LlabPhysicians 2018;10:221-25.

3. Fishman JA. Infection in organ transplantation. Am J Transplant 2017;17:956-79.

4. Allen UD, Preiksaitis JK, and the Infectious Disease Community of Practice. Ebstein-Barr Virus and Lymphoproliferative Disorder in solid organ transplantation. Am J Transplant 2013;13:107-20.

5. Scott H, James, Kimberlin DW. Herpes simplex virus in transplant recipients. Diakses pada 18 Juli 2018. Didapat dari: http://www.antimicrobe.org/t02.asp\#r51.

6. Len O, Garzoni C, Lumbreras C, Molina I, Meije Y, Pahissa A, dkk. Recommendations for screening of donor and recipient prior to solid organ transplantation and to minimize transmission of donor-derived infections. Clin Microbiol Infect 2014;20:10-8.

7. Fischer SA, Avery RK. Screening of donor and recipient prior to solid organ transplantation. Am J Transplant 2009;9:7-18.

8. Vella J, Bennet WM, Brenna DC. Cytomegalovirus infection in renal transplant recipients. USA: UpToDate-Wolters Kluwer. 2015. Diakses pada 21 Desember 2018. Didapat dari: https:// www. uptodate.com.

9. Cincinnati Children's Hospital Medical Center. Evidence-based care guideline: cytomegalovirus prevention following solid organ 
transplantation 2007. Diakses pada 26 Januari 2016. Didapat

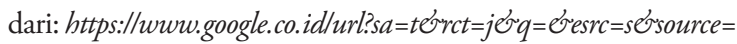
weberd $=10$ or $c$ ad $=$ rjatruact $=8$ orved $=0$ ahUKEwiyhKSaz8jKAh UDBo4KHcgtAKEQFghmMAkל url=http\%3A\%2F\%2Fwww. cincinnatichildrens.org\%2FWorkArea\%2FDownloadAsset.aspx\% 3Fid\%3D1095326usg=AFQjCNFvkOxL6dyRHCugNODQZr $8 q n n I x C w$.

10. Nicastro E, Giovannozzi S, Stroppa P, Casotti V, Callegaro AP, Tebaldi A, dkk. Effectiveness of preemptive therapy for cytomegalovirus disease in pediatric liver transplantation. Transplantation 2017;101:804-10.

11. Razonable RR, Humar A. Cytomegalovirus in solid organ transplantation. Am J Transplantation 2013;13:93-106.

12. Mallik M. Paediatric Renal transplantation guideline. Nottingham: Nottingham University Hospitals; 2013.

13. Lumbreras C, Manuel O, Len O, Berge IJM, Sgarabotto D, Hirsch HH. On behalf of the ESCMID study group of infection in compromised hosts. Cytomegalovirus infection in solid organ transplant recipients. Clin Microbiol Infect Dis 2014;20:19-26.

14. The Royal Children's Hospital Melbourne. CMV Prophylaxis, Disease and Treatment. Diakses pada 23 Januari 2016. Didapat dari: http://www.rch.org.au/nephrology/protocols/ renaltransplant/446_CMV_Prophylaxis_Disease_and_Treatment/.

15. Danziger-Isakov L, Kumar D. Vaccination in solid organ transplantation. Am J Transplant 2013;13:311-7.

16. Allen U, Alfieri C, Preiksaitis J, Humar A, Moore D, Tapiero $B$, dkk. Epstein-Barr virus infection in transplant recipients: summary of a workshop on surveillance, prevention and treatment. Can J Infect Dis 2002;13:89-99.

17. Pergam SA, Limaye AP. Varicella zoster virus in solid organ transplantation. Am J Transplant 2013;13:138-46.

18. Wilck MB, Zuckerman RA, the AST Infectious Disease Community of Practice. Herpes Simplex Virus in solid organ transplantation. Am J Transplant 2013;13:121-7. 